\title{
Rural Online Distance Education based on Content Delivery Network in Beijing
}

\author{
http://dx.doi.org/10.3991/ijoe.v11i7.4763 \\ Ji-chun ZHAO ${ }^{1,2}$, Shi-hong LIU², Jun-feng ZHANG ${ }^{1,3}$ \\ ${ }^{1}$ Beijing Academy of Agriculture and Forestry Sciences, Beijing, China \\ 2 Institute of Agricultural Information, Chinese Academy of Agricultural Sciences, Beijing, China \\ ${ }^{3}$ The Research Center of Beijing Engineering technology for Rural Remote Information Services, Beijing, China
}

\begin{abstract}
The paper proposed the research on rural online distance education (RODE) based on the Beijing rural network condition, which aimed at helping farmers to get agricultural technology more effectively and sufficiently. This is the first platform that was applied to large-scale rural distance education, which combined with peer to peer (P2P) and content delivery network(CDN). What's more, it initiates network video transmission into the RODE platform, which could save $80 \%$ of the bandwidth. In addition, MD5 encryption algorithm, content pre-reading technology and data logic chip technology were used to ensure the security of video data. It has the following advantages: easily deployed, highly scalable and low-cost.
\end{abstract}

Index Terms-Rural online distance education; Content delivery network; Video transmission

\section{INTRODUCTION}

Online distance education is becoming more and more prevalent in recent years, for instance, the key factor of economic development -education, the remarkable development of the telecommunication technology and the number of people involved in the education process itself.

The applications in the world dates back to 19th century. The application of online distance education has defined by Kaya and Karatas. In 1840, Isaac Pitman started to teach steno by letters. On Apr 20th, 1878, an advertisement was given in the American newspaper, Boston, about the lesson of steno that was given by letters. An advertisement was seen which included a lesson that given written expression lessons by letters in the last quarter part of $1800 \mathrm{~s}$.

In 1922, New Zealand Correspondence School was founded, and National College (NEC) was opened in 1974 which built the foundation of Open University. The sample institutions were "Ecole Universelle par Correspondance", opened in 1907 in Paris, and "Centre National d'Enseigment par Correspondence", opened in 1937. Australia is the country that was a good sample of system of distance online education in primary and secondary education. Online distance education was started in the Queensland University with tertiary degrees.

In 1948, Japan, online distance education was applied to students lived far away, and college and university students in military. In 1972, Spain started to provide national distance online education in the university. Spain, national distance online education was founded in university.
Holland Open University accepted their first students in the first days of September in 1984. Countries such as Canada, Indian, Israel, Italy and Poland developed and applied projects of distance online education.

We are interested in the problem of Video-on-Demand streaming using peer-to-peer (P2P) approach, which can be used to address several serious problems posed in existing VOD systems, for example, the infeasibility of IP Multicast, network bottleneck at the video server, and the high maintenance and deployment of dedicated overlay routers. Recently, there have been several research projects on live streaming using $\mathrm{P} 2 \mathrm{P}$ approach, the $\mathrm{P} 2 \mathrm{P}$ paradigm defines distributed systems, which all participating processes are equally important. To promote the process of rural online distance education platform, problems are mentioned as below:

1. The satellite and broadcasting platforms modes don't facilitate the teaching and statistical consulting data feedback because of less interactivity.

2. IPTV, Internet Protocol Television, needs high bandwidth and large investment in infrastructure.

3. Due to the constraints of the model in network or technology, teaching management and statistical functions are not very strong, the application result turned out not to be ideal.

According to the Beijing rural network infrastructure condition, RODE is mainly applied to e-government network and the Internet as a compliment using doctrine of the integration of resources principles. Taking the limited of government network bandwidth resources into account, which used ATM transmission and the maximum bandwidth is only $100 \mathrm{Mbps}$, RODE is apt to use P2P and $\mathrm{CDN}$ as a core application. We have solved the problems of network structure complex and the node cannot communicate with each other, to improve the video display fluency.

\section{MATERIALS AND METHODS}

\section{A. Solutions to the problem of inadequate bandwidth of e-government network}

Taking the service node contain a core node and 16 branches nodes into account, $\mathrm{P} 2 \mathrm{P}$ and $\mathrm{CDN}$ technology solutions made the edge of node divided into different districts of the autonomous domain, and the domain of the autonomous was deployed P2P services, which could enhance the capacity of the system level effectively. Video on demand media program could be pushed to the branch nodes store through the core node, and living 
stream media program could also be pushed to the branches nodes media server form the core node.

Allocation of $\mathrm{CDN}$ network infrastructure in theory happened in 1825, then showed up online service, and then turned up the application of P2P technology, P2P with CDN could increase this figure effectively. The P2P and CDN technology could expand the traditional living service business to 50-400 times than before and the traditional video on demand service business to $15-90$ times, and the reliability and quality of the RODE was high.

RODE had the topology of self-learning, selforganizing capacity. Users could share the same network bandwidth from the same network, and only need 1-2 users export bandwidth to make a stable and reliable application in the LAN, so to achieve multiple users in the LAN watching the same living and video on demand programs smoothly.

\section{B. Solutions to heterogeneous networks}

Implementation of the project in the e-government network, the network heterogeneity existed in the following aspects:

1)the heterogeneity of nodes

a. Nodes may come from different operators (aimed at e-government network, Telecom, Netcom, telecommunications links, etc.)

b. Node may access from different parties (including the specific circumstances of fiber access, ADSL access, Ethernet access, etc.)

c. Node may be the shared bandwidth of local area network or not.

d. Some of the node had a separate IP or in a NAT, others behind the multi-level NAT.

2) Node bandwidth asymmetry

For example, the common ADSL access way, the uplink bandwidth was often less than the downlink bandwidth.

\section{3) The randomness of the node}

Joining or exiting the network of the nodes could not be foreseen. Combination with prior knowledge and automatic measurement, which achieved application layer logical topology self-learning and self-adjustment, the logical topology and physical network topology could combine at maximum. What's more, the users of the same operator could be arranged in the same logical network as far as possible. There are five ways to solve the problems:

1) RODE could use for maximum bandwidth utilization via multiple threads in parallel transferring. Meanwhile, it could improve the inter-carrier, cross-regional network interoperability results.

2) According to the node access bandwidth and service capacity, the node role was adjusted by the way of dynamic measurement and perception.

3) Automatic detection of LAN users could achieve multi-user viewing of the logical network selforganization, self-tuning, and it could be possible for multicast in small rang.

4) Through the firewall made the node from the LAN , application of UDP transmission technology can also be equal participation of $\mathrm{P} 2 \mathrm{P}$ services, to achieve maximum bandwidth utilization.
5) Under the circumstances, dynamic monitoring and adjustment of the node online operation, it could dynamically adjust the changes in the structure, which encountered normal or abnormal exit nodes.

\section{P2P and CDN deployment strategy}

The central node bandwidth is limited and could not afford simultaneously access from a large number of users. To maximize the advantages of $\mathrm{P} 2 \mathrm{P}$ data distribution strategy, the following deployment strategies are applied.

1) The strategy of CDN was that the 16 branches nodes video programs were the same as on the core node.

2) In order to decrease the pressure on the central server, P2P access policy was that users could only access the local district peers according to IP segment, the P2P and CDN data distribution strategy is shown in Figure 1.

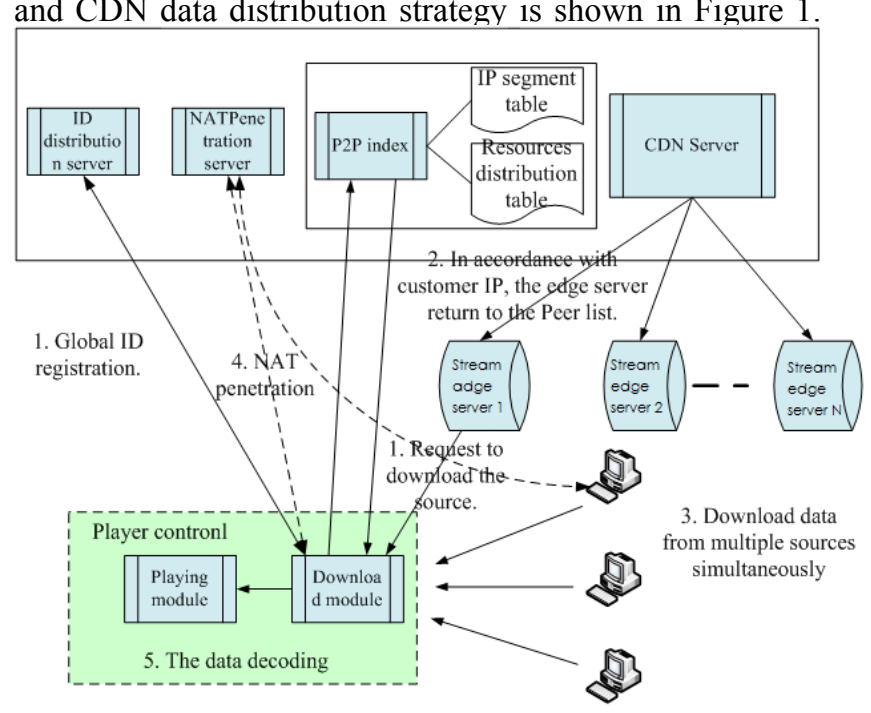

Figure 1. The P2P and CDN data distribution strategy

\section{THE EXPERIMENT RESULTS}

There are the function of education, modern agricultural science and technology promotion, information dissemination and consultation in RODE, which was promoted and applied in 183 towns and 3,934 villages in Beijing, and the number of registered users could be over four million. Now the video teaching resources have uploaded about 9000, and the cumulative duration has more than 5000 hours, the cumulative update information has been over 40,000 . It greatly enriched the basic science and technology promotion, rural training education, agricultural technology services.

RODE for 183 towns and 3934 villages in Beijing is tested using living video stream $800 \mathrm{Kbps}$, and the test results showed that when the number of user is 3000 (Figure 2) on the line, in theory, the bandwidth is required for the $240 \mathrm{M}$, but in fact the real bandwidth is only $48 \mathrm{M}$ (Figure 3 and Figure 4). It is proved that about $80 \%$ network bandwidth is saved, the video played fluently, and with better feedback. 
Traffic Analysis for 10.165.0.165 -hai dianliumeiti. local domain

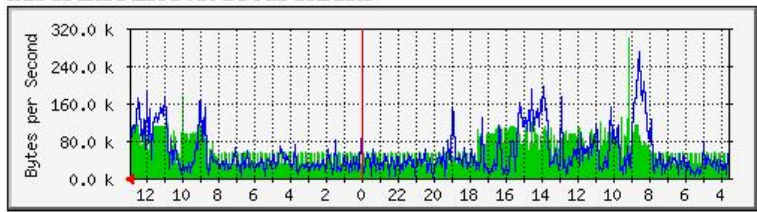

Traffic Analysis for 172. 25.124. 44 -huairouliumeiti. local domain

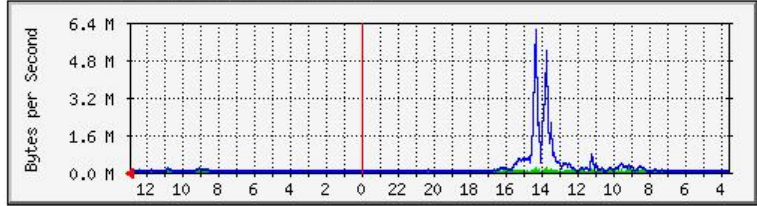

Traffic Analysis for 172.25.81.47 -chaoyangliumeiti. local domain

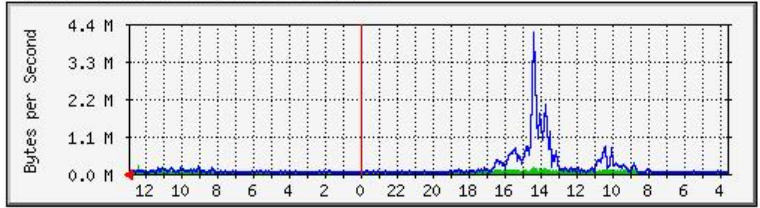

Figure 2. The network bandwidth value

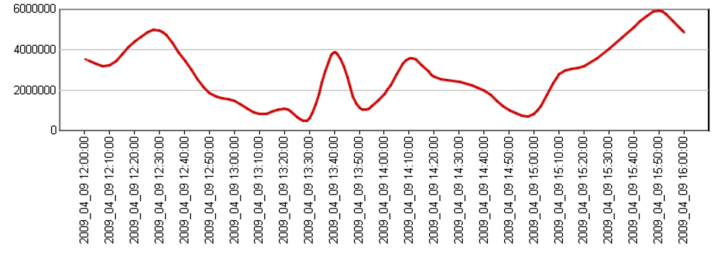

Figure 3. The total value of network bandwidth

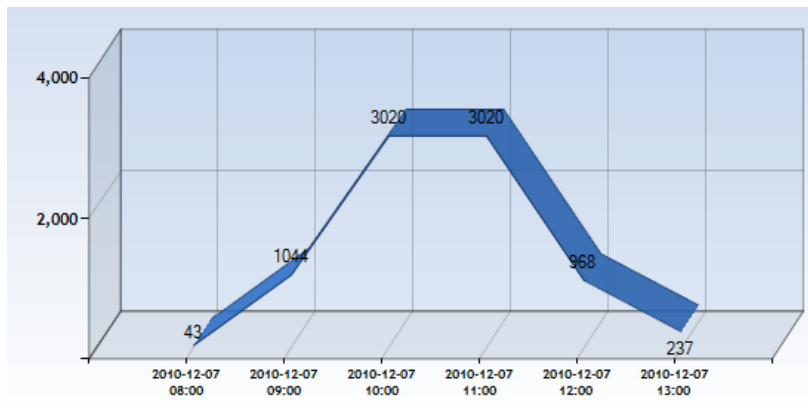

Figure 4. The number of On-line users

\section{DISCUSSION AND CONCLUSIONS}

Generally speaking, RODE visitors have more than 3.6 million accesses, the living video and video on demand (VOD) is about 350,000 times, the learning program length is about 300,000 hours, all learning material can be achieved in the website of www.bjcc.gov.cn and www.bjcc.egov.cn, the number of trainees is over 2.5 million. The RODE had transmitted rural technologies in rural areas more than 1500 , providing a strong support to the promotion of advanced agricultural science and technology achievements, and enhanced the development of rural information. Compared with IPTV platform mode, satellite mode as well as broadcast mode, FDOE possess more advantages in the Interactivity, Video on demand, Scalability, Stability and Investment scale(TABLE I ). Compared with other distance online education modes, RODE saves network bandwidth and server resources significantly, RODE's Video delay and video response time is shorter, and video quality is better. RODE is with high security and stability, strong controllability and manageability, and low cost in maintenance(TABLE II ).

TABLE I. THE FDOE IS COMPARED WITH IPTV PLATFORM

\begin{tabular}{|c|c|c|c|c|}
\hline $\begin{array}{c}\text { Index } \\
\text { name }\end{array}$ & RODE & $\begin{array}{c}\text { IPTV } \\
\text { mode }\end{array}$ & $\begin{array}{c}\text { Satellite } \\
\text { mode }\end{array}$ & $\begin{array}{c}\text { Broad } \\
\text { casting } \\
\text { mode }\end{array}$ \\
\hline $\begin{array}{c}\text { Interactivit } \\
\text { y }\end{array}$ & $\begin{array}{c}\text { Supporting } \\
\text { audio and } \\
\text { text } \\
\text { interaction }\end{array}$ & $\begin{array}{c}\text { Supporting } \\
\text { text } \\
\text { interaction }\end{array}$ & No & No \\
\hline $\begin{array}{c}\text { Video on } \\
\text { demand }\end{array}$ & $\begin{array}{c}\text { Choosing } \\
\text { free }\end{array}$ & $\begin{array}{c}\text { Choosing } \\
\text { free }\end{array}$ & No & No \\
\hline $\begin{array}{c}\text { Scalability } \\
\text { High }\end{array}$ & Low & Low & Low \\
\hline Stability & High & low & Low & High \\
\hline $\begin{array}{c}\text { Investment } \\
\text { scale }\end{array}$ & Small & Large & Large & Large \\
\hline \multicolumn{2}{|r|}{ MODE, SATELLITE MODE AND BROADCAST MODE } \\
\end{tabular}

TABLE II. COMPARED WITH THE OTHER DISTANCE ONLINE EDUCATION MODE.

\begin{tabular}{|c|c|c|c|}
\hline \multicolumn{2}{|c|}{ Index name } & \multirow{2}{*}{$\begin{array}{c}\text { RODE } \\
80 \%\end{array}$} & \multirow{2}{*}{$\begin{array}{c}\begin{array}{c}\text { Similar to } \\
\text { the other } \\
\text { distance } \\
\text { online }\end{array} \\
\begin{array}{c}\text { education } \\
\text { mode }\end{array} \\
20 \%\end{array}$} \\
\hline \multirow{3}{*}{$\begin{array}{l}\text { Network } \\
\text { bandwidth } \\
\text { and server } \\
\text { resource } \\
\text { consumption }\end{array}$} & $\begin{array}{c}\text { Resources } \\
\text { inspiration rate } \\
\text { Number of } \\
\end{array}$ & & \\
\hline & $\begin{array}{l}\text { Video server } \\
\text { CPU utilization }\end{array}$ & $\begin{array}{l}20-30 \% \\
\text { reduction }\end{array}$ & $\begin{array}{l}10-20 \% \\
\text { reduction }\end{array}$ \\
\hline & $\begin{array}{l}\text { single server } \\
\text { supports } \\
\text { concurrent }\end{array}$ & 1000 & 500 \\
\hline \multirow{3}{*}{ Video quality } & $\begin{array}{l}\text { Video delay } \\
\text { time }\end{array}$ & $7-8$ seconds & $\begin{array}{c}15-16 \\
\text { seconds }\end{array}$ \\
\hline & $\begin{array}{c}\text { Video response } \\
\text { time }\end{array}$ & 4-5 seconds & $7-8$ seconds \\
\hline & Video size & $\begin{array}{c}320 * 240, \\
480 * 320, \\
720 * 576\end{array}$ & $\begin{array}{l}320 * 240 \\
480 * 320\end{array}$ \\
\hline \multirow{3}{*}{$\begin{array}{c}\text { Security, } \\
\text { stability and } \\
\text { operation } \\
\text { maintenance } \\
\text { costs }\end{array}$} & $\begin{array}{l}\text { Content } \\
\text { security }\end{array}$ & $\begin{array}{c}\text { MD5 } \\
\text { encryption } \\
\text { algorithm } \\
\text { and the data } \\
\text { slice } \\
\text { technology } \\
\text { combined }\end{array}$ & $\begin{array}{l}\text { MD5 } \\
\text { encryption } \\
\text { algorithm }\end{array}$ \\
\hline & Stability & High & General \\
\hline & $\begin{array}{l}\text { Controllability } \\
\text { and } \\
\text { Manageability }\end{array}$ & $\begin{array}{c}\text { Focusing on } \\
\text { the } \\
\text { distributed } \\
\text { architecture, } \\
\text { P2P traffic } \\
\text { will be } \\
\text { strictly } \\
\text { limited to the } \\
\text { same edge } \\
\text { node. }\end{array}$ & Weak \\
\hline
\end{tabular}




\section{REFERENCES}

[1] Mario De Blasi, Carlo des Dorides, Advanced solutions for distance learning via satellite, in: computer communications, 26 (2003) 423-429 http://dx.doi.org/10.1016/S0140-3664(02)00162근

[2] Karatas, S. (2003). Distance Learning Application in Turkey and in the World, Available from: http://www.bote.gazi.edu.tr/boteabd/bto309/dunyadaue.ppt, (15.11.2008).

[3] Kaya, Z. (2002). Distance Training, Available from: http://www.canaktan.org/egitim/egitim-metodoloji/uzaktanegitim.htm, (12.11.2008).

[4] A. Marsap, M. Narin, The integration of distance learning via internet and face to face learning: Why face to face learning is required in distance learning via internet? in: Procedia Social and $\begin{array}{lllll}\text { Behavioral } & \text { Sciences } & 1 & \text { (2009) } & \text { 2871-2878 }\end{array}$ http://dx.doi.org/10.1016/j.sbspro.2009.01.510

[5] D. Schoder, K. Fischbach, Peer-to-Peer Paradigm, Proc. in: 37th IEEE Int'1 Conference on System Sciences, Hawaii, USA, 2004. http://dx.doi.org/10.1109/hicss.2004.1265469

[6] E. Ahi, M. Caglar, O. Ozkasap, Stepwise Fair-Share Buffering underneath Bio-inspired P2P Data Dissemination, Proc. in: 6th International Symposium on Parallel and Distributed Computing (ISPDC'07), Hagenberg, 2007. http://dx.doi.org/10.1109/ISPDC.2007.54

[7] M. Amoretti, A Framework for Evolutionary Peer-to-Peer Overlay Schemes, in: European Workshops on the Applications of Evolutionary Computation (EvoWorkshops 2009), Tubingen, Germany, April 2009. http://dx.doi.org/10.1007/978-3-642-01129$\underline{0} 7$

[8] Katia Passerini, Mary J. Granger, A developmental model for distance learning using the Internet, in: Computers \& Education 34 (2000) 1-15. http://dx.doi.org/10.1016/S0360-1315(99)00024$\mathrm{X}$

[9] D.A. Tran, K.A. Hua, T.T. Do, A peer-to-peer architecture for media streaming, in: IEEE Journal on Selected Areas in $\begin{array}{llllllll}\text { Communications } & 22 & \text { (1) } & \text { (2004) } & 121 & \text { - } & 133 .\end{array}$ http://dx.doi.org/10.1109/JSAC.2003.818803

[10] S. Banerjee, B. Bhattacharjee, C. Kommareddy, Scalable application layer multicast, in: SIGCOMM, 2002, pp. $205-217$. http://dx.doi.org/10.1145/633025.633045
[11] M.B.H. Deshpande, H. Garcia-Molina, Streaming live media over a peer-to-peer network, in: CS-Stanford (2002).

[12] V.N. Padmanabhan, H.J. Wang, P.A. Chou, K. Sripanidkulchai, Distributing streaming media content using cooperative networking, in: NOSSDAV, 2002, pp. 177 - 186. http://dx.doi.org/10.1145/507670.507695

[13] Katia Passerini, Mary J. Granger, Robust video-on-demand streaming in peer-to-peer environments, in: Computer

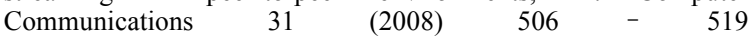
http://dx.doi.org/10.1016/j.comcom.2007.08.024

[14] Simonson, M., and C. Schlosser. 1995. More than fiber: Distance education in Iowa, in: Tech Trends 40 (3): 13-15. http://dx.doi.org/10.1007/BF02818826

[15] Michael Simonson, Charles Schlosser and Dan Hanson, Theory and Distance Education: A new Discussion, in: The American Journal of Distance Education Vol. 13 No.1 http://dx.doi.org/10.1080/08923649909527014

\section{ACKNOWLEDGMENT}

This research was sponsored by National Science and Technology Support Program(Project No. 2014BAD10B02), which is construction and application of provincial rural information service platform in developed area, and supported by Distance Education Innovation Team Project of Beijing Academy of Agriculture and Forestry Sciences.

\section{AUTHORS}

Ji-chun ZHAO is with Beijing Academy of Agriculture and Forestry Sciences, Beijing, China (e-mail: zhaojichun_0@163.com).

Shi-hong LIU is with Institute of Agricultural Information, Chinese Academy of Agricultural Sciences, Beijing, China (e-mail: lius@mail.caas.net.cn).

Jun-feng ZHANG is with Beijing Academy of Agriculture and Forestry Sciences, Beijing, China (e-mail: zhangjf@agri.ac.cn).

Submitted 25 May 2015. Published as resubmitted by the author 25 june 2015 . 